\title{
Diagnostic criteria for proliferative hepatic lesions in brown bullhead Ameiurus nebulosus
}

\author{
Vicki S. Blazer ${ }^{1, *}$, John W. Fournie ${ }^{2}$, Jeffrey C. Wolf ${ }^{3}$, Marilyn J. Wolfe ${ }^{3}$ \\ ${ }^{1}$ National Fish Health Research Laboratory, US Geological Survey, 11649 Leetown Road, Kearneysville, West Virginia 25430, USA \\ ${ }^{2}$ U.S. Environmental Protection Agency, Gulf Ecology Division, 1 Sabine Island Drive, Gulf Breeze, Florida 32561, USA \\ ${ }^{3}$ The Registry of Tumors in Lower Animals, 22900 Shaw Road, Suite 107, Sterling, Virginia 20166, USA
}

\begin{abstract}
Brown bullhead Ameiurus nebulosus is used as indicator species for contaminant effects at areas of concern (AOC) in the Great Lakes and other areas. One of the beneficial use impairments at numerous AOC is 'fish tumors and other deformities'. An impairment occurs when the prevalence of fish tumors and other deformities exceeds those at unimpacted or control sites or when survey data confirm the presence of neoplastic or preneoplastic liver lesions in bullhead or white sucker Catostomus commersonii. Numerous surveys have been conducted over the years assessing neoplasia in these fishes, both liver and skin tumors. However, a major problem in comparing the results has been a lack of consistent criteria for evaluating histological changes in bullhead livers. As individual AOC develop and implement remedial action plans, realistic and attainable delisting targets need to be specified. For this to occur and be consistent from site to site there must be standardization of the criteria being used to evaluate specific impairments. In this report, specific diagnostic criteria are provided for both non-neoplastic and neoplastic proliferative hepatocellular and biliary lesions. These criteria should assist fish pathologists in describing and categorizing proliferative liver lesions from brown bullhead.
\end{abstract}

KEY WORDS: Brown bullhead $\cdot$ Liver $\cdot$ Neoplasia $\cdot$ Proliferative lesions $\cdot$ Diagnostic criteria

\section{INTRODUCTION}

The International Joint Commission (IJC), comprised of American and Canadian officials, was formed in 1909 to assist their governments in finding solutions to the problems facing the waters bordering the United States and Canada. The Great Lakes Water Quality Agreement, in which the United States and Canada agreed to restore and preserve the biological, physical and chemical integrity of the Great Lakes Basin Ecosystem, was first signed in 1972. In 1987 a protocol was signed by both governments which defined Great Lakes areas of concern (AOC) as 'geographic areas that fail to meet the general or specific objectives of the agreement where such failure has caused or is likely to cause impairment of beneficial use of the area's ability to support aquatic life'. The US and Canadian governments identified 43 such areas; 26 in the US, 12 in
Canada, and 5 shared between the US and Canada on connecting river systems. The Great Lakes Water Quality Agreement, as amended via the 1987 protocol, directs the 2 federal governments to cooperate with state and provincial governments to develop and implement remedial action plans (RAPs) for each AOC. The protocol also called for reports on restorative progress and for the IJC to review RAPs proposed by the 43 AOC. To date, 2 AOC (Collingwood Harbor and Severn Sound) have been delisted (IJC 1987) and Presque Isle Bay has been designated an area of recovery.

So far, 14 beneficial use impairments have been identified and the various AOC have different combinations of these impairments. One impairment, listed as 'fish tumors and other deformities' is defined as occurring when 'the incidence rate of fish tumors and other deformities exceeds rates at unimpacted or control sites or when survey data confirm the presence of 
neoplastic or preneoplastic liver tumors in bullhead or suckers' (IJC 1989; www.epa.gov/lakeerie/buia/reports). Deformities are defined as twisted, missing, forked or bulging body parts including fins, barbels, abdomen or skeleton. Currently, 16 of the 41 AOC have the presence of tumors or other deformities listed as one of their beneficial use impairments.

A key indicator species for AOC is the brown bullhead Ameiurus nebulosus (IJC 1987), because this is a bottom-dwelling fish with a limited home range and is known to take up contaminants from food and sediments (Maccubbin et al. 1985, Baumann 1989, Baumann et al. 1991, 1996, Smith et al. 1994). Both liver (Harshbarger \& Clark 1990, Baumann \& Harshbarger 1995, Pinkney et al. 2001) and skin (Black 1983, Smith et al. 1989, Bowser et al. 1991, Poulet et al. 1994) neoplasms have been associated with exposure to polynuclear aromatic hydrocarbons (PAH) and other contaminants. Although the prevalence of skin neoplasia is often elevated in fish from chemically polluted, often industrial, sites (Sonstegard 1977, Hayes et al. 1990, Bowser et al. 1991), the association of epidermal papillomas and carcinomas with chemical exposure is less conclusive than with liver neoplasia (Poulet et al. 1994). There is also good evidence for the influence of PAH exposure on the development of liver neoplasm and other microscopic liver lesions in other fish species, including English sole Parophrys vetulus (Myers et al. 1990), mummichog Fundulus heteroclitus (Vogelbein et al. 1990) and winter flounder Pseudopleuronectes americanus (Gardner et al. 1989).

Numerous surveys have been undertaken to assess the prevalence of skin and liver tumors, as well as other contaminant-associated lesions at AOC. However, a major problem has been a lack of consistent criteria for evaluating histological changes in bullhead livers. For instance, in some studies there is no distinction between altered foci (preneoplastic) and neoplastic lesions, or inadequate descriptions of individual lesions (Black 1983, Pyron et al. 2001). Baumann et al. (2000) present a compilation of liver neoplasm prevalence at AOC by location and year. However, a comparison of the papers/reports from which these data were obtained demonstrates the lack of consistent criteria. For example, a prevalence of $7 \%$ was noted in the Ashtabula River in 1991 by Mueller \& Mac (1994). In that study, neoplasia included only hepatocellular carcinoma (advanced liver neoplasms) or cholangiocarcinoma (biliary neoplasms), but not hepatocellular adenoma, cholangioma or altered foci (Mueller \& Mac 1994). Conversely, the prevalence reported for the Black River in 1982 (60\%) included carcinomas and adenomas (Baumann et al. 1990), while the $9 \%$ in the Detroit River in 1985 to 1987 included carcinomas, adenomas and altered foci (Maccubbin \& Ersing 1991).
An RAP is required for each AOC. The intent is to provide a strategic guideline that outlines all phases of the remedial effort, from problem definition to active remediation, through to the recovery stage and, finally, delisting. A key component of these plans is the specification of realistic and attainable delisting targets and the collection of data necessary to demonstrate that the beneficial use is no longer impaired. For the 'fish tumors and other deformities' impairment, there are 2 primary issues that require resolution: (1) the standardization of the criteria being used to evaluate the impairment, and (2) the institution of realistic delisting targets. Criteria need to be established for both sampling and monitoring this impairment so that data from different years, reference sites and AOC can be compared.

Diagnostic criteria already exist for non-neoplastic and neoplastic liver lesions in some fish species such as English sole Parophrys vetulus, medaka Oryzias latipes, the common dab Limanda limanda and European flounder Platichthys flesus (Myers et al. 1987, Boorman et al. 1997, Feist et al. 2004). Even though liver lesions in a variety of fish species are very similar, it is useful to provide detailed descriptions and illustrations for species commonly used in laboratory studies and monitoring programs. Therefore, the purpose of this report was to address the need for diagnostic criteria for proliferative liver lesions in bullhead and to suggest a classification system for these lesions. Commonly observed non-neoplastic and neoplastic proliferative lesions are described and illustrated to provide guidelines to assist pathologists evaluating studies utilizing these fish as indicator or sentinel species, particularly in the Great Lakes.

\section{MATERIALS AND METHODS}

Material for this review was obtained from numerous field collections of brown bullheads, primarily from tributaries of Lake Erie but including other sites such as the Hudson River (New York), and ponds on Cape Cod (Massachusetts), where bullhead have been used as an indicator species for assessing environmental stress. These include liver samples from over 1500 brown bullhead collected from 1998 to the present, for which histologic slide collections are housed at the US Geological Survey's National Fish Health Research Laboratory, Kearneysville, West Virginia. These studies involved random samples of fish from specific sites, and the proliferative lesions observed microscopically were not often associated with grossly visible liver lesions. In addition, the National Cancer Institute's Registry of Tumors in Lower Animals, Sterling, Virginia, currently has 991 brown bullhead cases from numerous surveys dating from 1965 to 2001. Approxi- 
mately 680 of these cases had previously been diagnosed with liver neoplasms and we reviewed 25 cases for specific lesions. Many of the cases in the Registry were associated with grossly observable lesions. Most of the above studies targeted fish 3 yr of age or older, with a total length of $250 \mathrm{~mm}$ or greater. Typically, tissue was fixed in $10 \%$ buffered formalin, embedded in paraffin, sectioned at 3 to $6 \mu \mathrm{m}$ and stained with hematoxylin and eosin.

Slides were examined with a Nikon Eclipse E600 microscope with Plan Apochromatic lenses and a Spot RT Slider ${ }^{\mathrm{TM}}$ (Model 2.3.1) high resolution digital camera system (Diagnostic Instruments). Images were captured from the system using $\operatorname{Spot}^{\mathrm{TM}}$ (Version 3.3 for Windows ${ }^{\circledR}$ ) capture software at $1600 \times 1200$ dots per inch (dpi) resolution. Brightness/contrast adjustments were performed in Adobe Photoshop ${ }^{\circledR} 6.0$ for Windows (Adobe Systems).

\section{RESULTS}

\section{Normal hepatic histology of brown bullhead}

As in most teleosts, the liver of brown bullhead is composed of hepatic tubules. The classic hexagonal architecture of the mammalian hepatic lobule is not evident in fish livers (Gingerich 1982, Vethaak \& Wester 1996, Metcalfe 1998, Hinton et al. 2001). The appearance of teleost hepatocytes can vary greatly due to sex, maturity, diet, season, contaminant exposure and other factors (Hinton \& Couch 1998, Rocha \& Monteiro 1999). Normal hepatocytes may have little or no observable lipid or glycogen storage (vacuolization) (Fig. 1A) or may contain extensive amounts of these stored energy sources (Fig. 1B). Exocrine pancreatic tissue and macrophage aggregates are commonly present (Fig. 1C,D) and bile ducts may also be observed
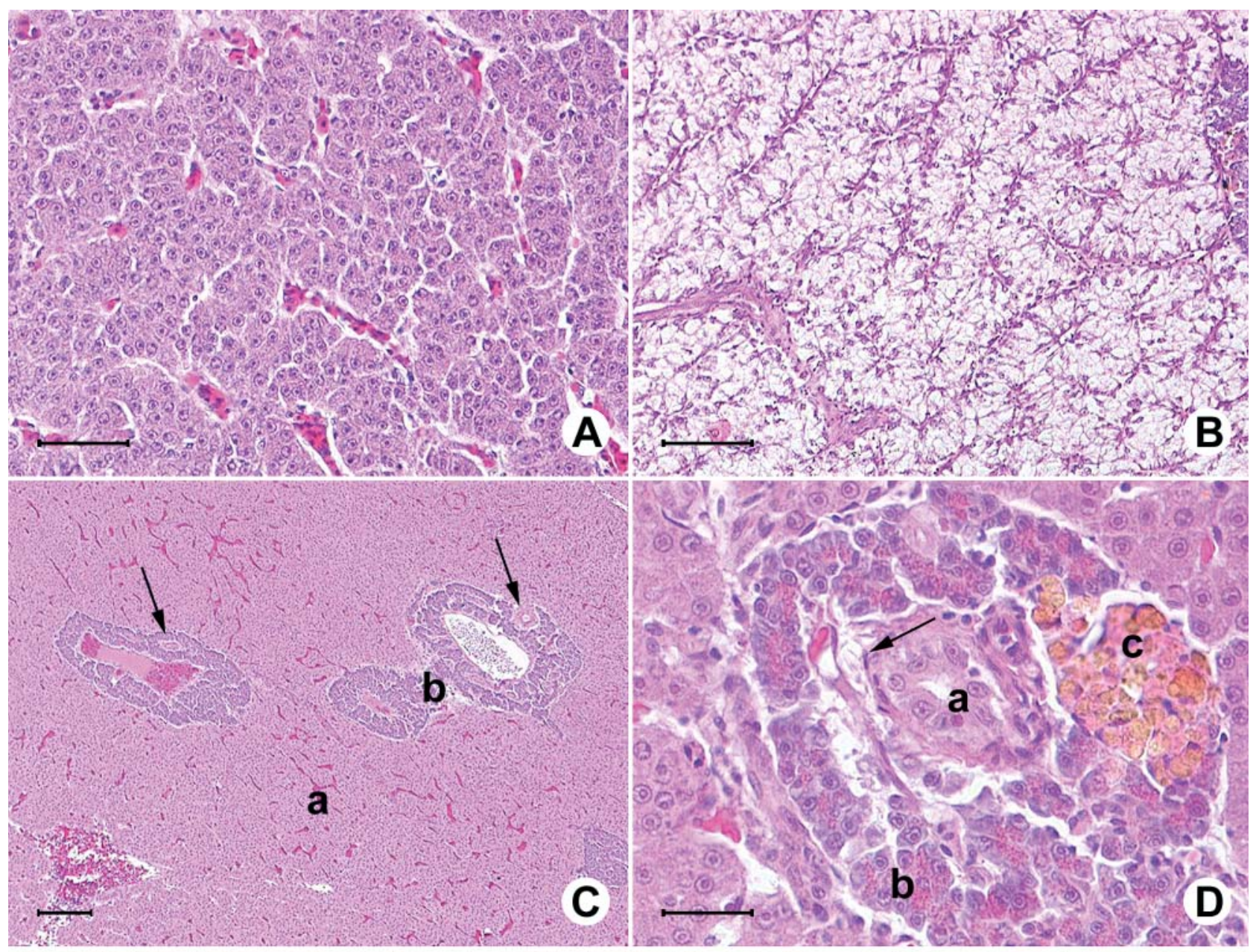

Fig. 1. Ameiurus nebulosus. Microscopic appearance of normal liver of brown bullhead. (A,B) Normal hepatocyte appearance can vary from (A) relatively unvacuolated to (B) significant vacuolization due to lipid and glycogen storage. Scale bars $=50 \mu \mathrm{m}$. (C) Within liver parenchyma (a), exocrine pancreatic tissue (b) often surrounds vessels and bile ducts (arrows). Scale bar = $100 \mu \mathrm{m}$. (D) Bile ducts (a) have a low columnar epithelium and are surrounded by a thin band of connective tissue (arrow); pancreatic tissue (b) and macrophage aggregates (c) are often observed in this area. Scale bar $=25 \mu$ m. Hematoxylin \& eosin 
within this tissue. In liver sections from bullheads collected at reference sites, bile ducts are often sparsely distributed in sections examined by light microscopy, although numerous bile preductules and ductules are located within the hepatic parenchyma (Hinton \& Couch 1998). Small and intermediate bile ducts have columnar epithelium and the ducts are encircled by a thin band of connective tissue (Fig. 1D). Large bile ducts are surrounded by connective tissue and are prominent near the common bile duct.

\section{Proliferative lesions in brown bullhead liver}

As in higher vertebrates, proliferative lesions of either hepatocellular or biliary origin can be categorized as putative pre-neoplastic, non-neoplastic or neoplastic.

Putative pre-neoplastic hepatocellular lesions: foci of cellular alteration

Based on tinctorial characteristics of the hepatocyte cytoplasm, 4 categories of altered foci can be recognized in hematoxylin and eosin-stained sections. These include basophilic foci, eosinophilic foci, vacuolated cell foci and clear cell foci. Foci are generally distinct in terms of coloration, but the hepatic tubules are arranged in a relatively normal pattern, and they merge imperceptibly with the surrounding parenchyma with little to no compression. Features of cellular atypia (increased nuclear to cytoplasmic ratio, nuclear pleomorphism, nucleolar enlargement, or the presence of coarsely clumped chromatin) are not generally evident.

- Basophilic foci are round to irregular clusters of hepatocytes with increased basophilic staining compared to adjacent cells (Fig. 2A). There is no evidence of compression of adjacent unaffected hepatic tissues, little to no atypia of hepatocytes, and mitotic figures are generally not present. In some lesions, constituent cells may be smaller than adjacent hepatocytes (Fig. 2B).

- Eosinophilic foci are round to irregular areas of hepatocytes with increased eosinophilic staining compared to adjacent cells (Fig. 2C). There is little to no evidence of compression; however, the cells may be slightly enlarged with granular eosinophilic cytoplasm (Fig. 2D).

- Vacuolated cell foci are round to irregular, blend into the surrounding parenchyma without compression, and contain hepatocytes with clear cytoplasmic vacuoles of varying sizes (Fig. 2E). Nuclei are often eccentrically located within the cells (Fig. 2F). Because the cytoplasmic lipid is often present in a micro- vesicular form, at low magnification the vacuolated foci may resemble clear cell foci.

Clear cell foci, as described in other fish species, with a 'ground glass' appearance of the cytoplasm, indicative of glycogen storage, and centrally located nuclei (Feist et al. 2004, Köhler 2004) were not observed in the bullhead livers examined. Occasionally individual cells within a vacuolated focus appeared to contain both lipid and glycogen and it is possible that bullhead foci may contain both storage products.

\section{Neoplastic hepatocellular lesions}

\section{Hepatocellular adenoma}

Adenomas are usually single discrete lesions with distinct borders (Fig. 3A). The cells often exhibit altered staining properties, either more eosinophilic or more basophilic than the non-neoplastic liver, and usually exhibit altered growth patterns (Fig. 3B). Macrophage aggregates, pancreatic tissue and other structures are often missing or sparse within adenomas (Fig. 3A-C). Adenomas are often well demarcated by compression of the adjacent parenchymal cells (Fig. 3C) and mitotic figures are rarely observed.

\section{Hepatocellular carcinoma}

Hepatocellular carcinomas are usually distinctly different from the surrounding liver tissue and have irregular borders due to invasion of neoplastic cells into the adjacent hepatic parenchyma (Fig. 3D). Carcinomas may be small or large lesions and may feature tumor giant cell formation. In some cases, foci of neoplastic cells are diffusely spread throughout the hepatic parenchyma (Fig. 3E). Cellular pleomorphism and nuclear atypia are key features, and there may be an increase in the number of mitotic figures and/or cells with multiple nucleoli (Fig. 3F).

\section{Non-neoplastic biliary lesions: bile duct hyperplasia}

Bile duct hyperplasia is characterized by an increased number of bile ducts (Fig. 4A) compared to normal liver (Fig. 4B). Hyperplastic bile ducts are often scattered and do not necessarily form discrete masses. The biliary epithelium is always well-differentiated; however, there may be moderate fibrosis associated with proliferating bile ducts (Fig. 4C), and the ducts tend to display substantial variation in size and shape. Occasionally the periductal fibrosis can be extensive (Fig. 4D). 


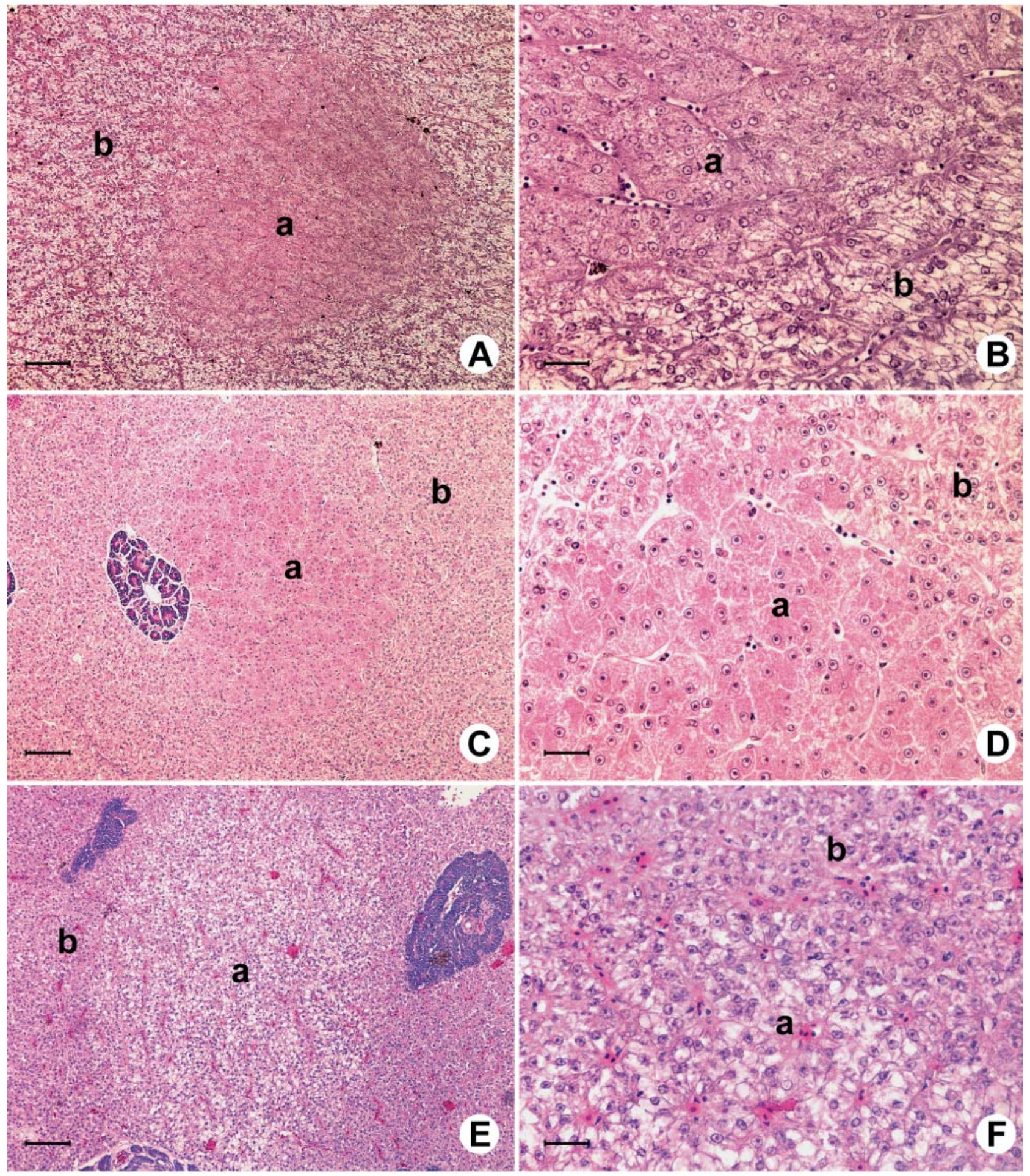

Fig. 2. Ameiurus nebulosus. Foci of cellular alterations in brown bullhead liver. (A) Basophilic focus (a) comprised of groups of hepatocytes with increased basophilic staining compared to surrounding hepatocytes (b). Scale bar = $100 \mu \mathrm{m}$. (B) Cells within basophilic focus (a) show little to no atypia and the border between these cells and surrounding hepatocytes (b) is distinct. Scale bar $=25 \mu \mathrm{m}$. (C) Eosinophilic focus (a) comprised of hepatocytes with increased eosinophilic staining compared to surrounding parenchyma (b). Scale bar $=100 \mu \mathrm{m}$. (D) Cells within an eosinophilic focus (a) may be slightly larger than surrounding cells (b) and have a granular cytoplasm. Scale bar $=25 \mu \mathrm{m}$. (E) Vacuolated focus is round to irregular and contains vacuolated hepatocytes (a) when compared to surrounding cells (b). Scale bar $=100 \mu \mathrm{m}$. (F) Cells within a vacuolated focus (a) contain vacuoles of varying size and nuclei may be peripherally located. Scale bar $=25 \mu \mathrm{m}$. Hematoxylin \& eosin 


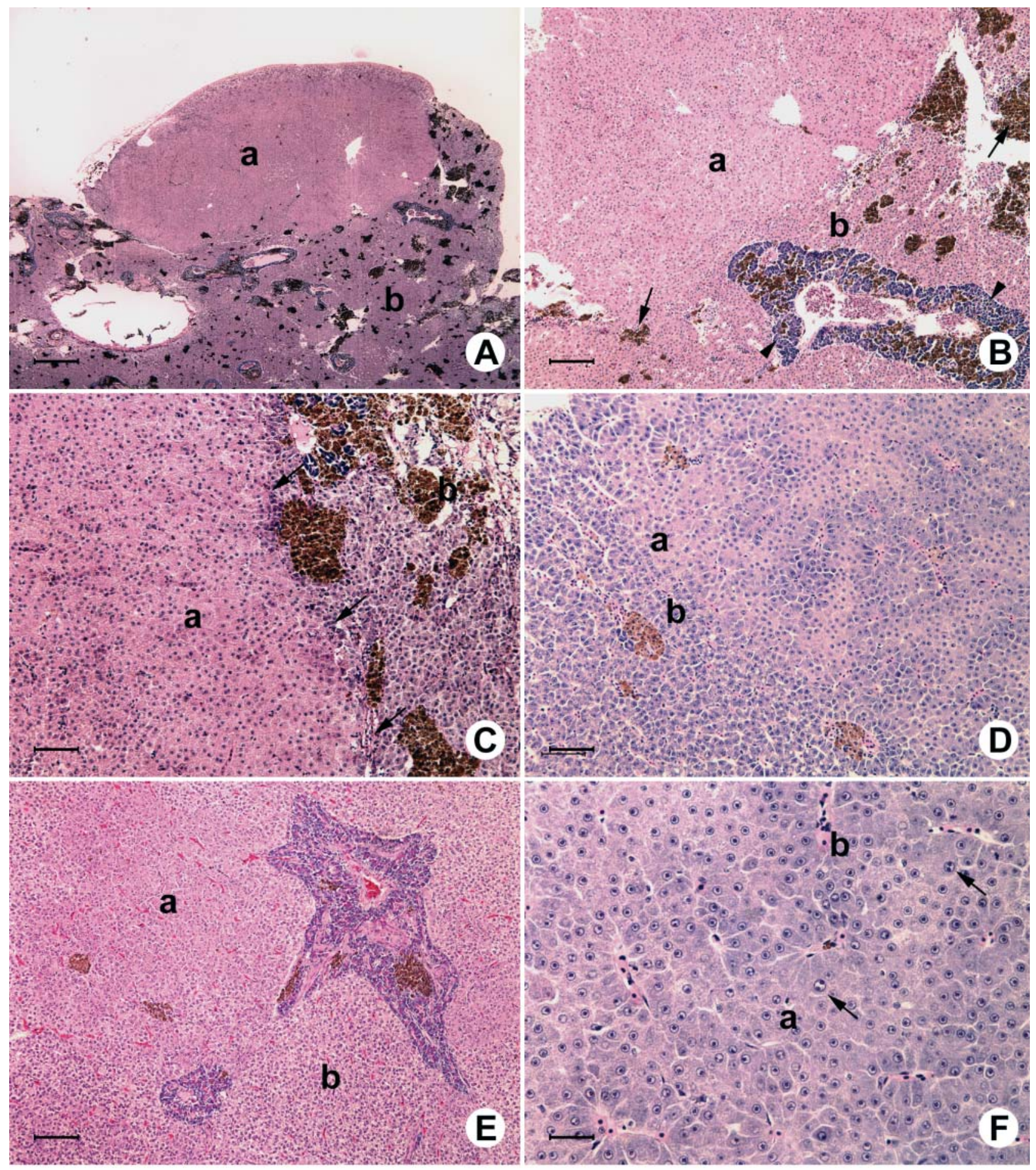

Fig. 3. Ameiurus nebulosus. Neoplastic hepatocellular lesions in brown bullhead liver. (A) Hepatocellular adenoma is a discrete nodule (a), well demarcated from normal tissue (b). Scale bar $=500 \mu \mathrm{m}$. (B) Neoplastic cells within hepatocellular adenomas (a) often stain more eosinophilic than normal cells (b); pancreatic tissue (arrowheads) and macrophage aggregates (arrows) are generally absent or scarce within the adenoma. Scale bar $=100 \mu \mathrm{m}$. (C) Cells within hepatocellular adenomas (a) usually exhibit altered growth patterns and are demarcated by compression of adjacent hepatocytes (arrows). Scale bar $=50 \mu \mathrm{m}$. (D) Hepatocellular carcinoma showing irregular border with neoplastic cells (a) extending into and sometimes surrounding the normal hepatocytes (b). Scale bar $=50 \mu \mathrm{m}$. (E) Hepatocellular carcinoma exhibiting a more diffuse appearance with multiple foci of neoplastic cells (a) interspersed with normal hepatcytes (b). Scale bar $=100 \mu \mathrm{m}$. (F) Neoplastic cells within hepatocellular carcinoma are pleomorphic, exhibit nuclear atypia including multiple nucleoli (arrows). Scale bar $=25 \mu \mathrm{m}$. Hematoxylin \& eosin 

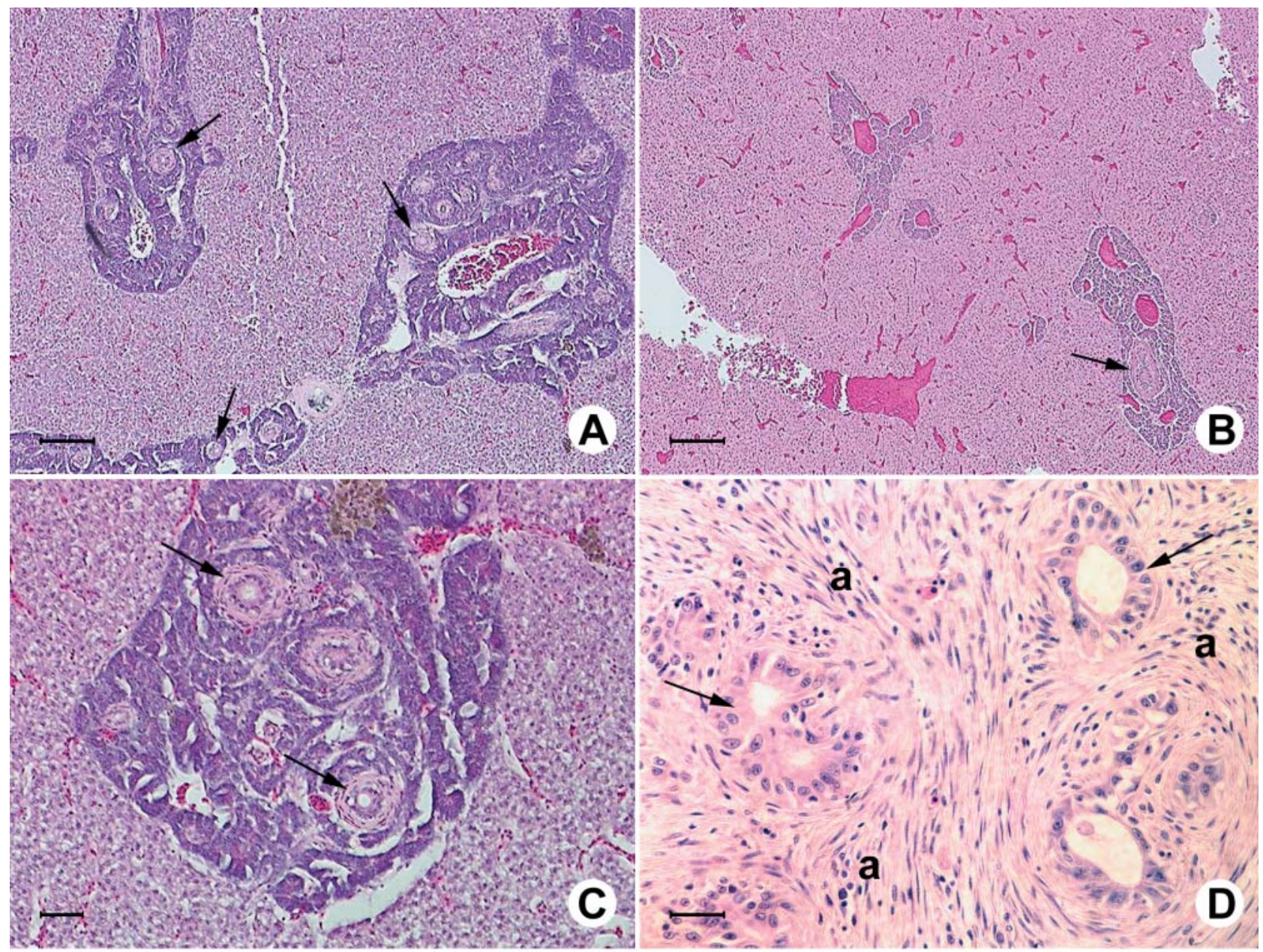

Fig. 4. Ameiurus nebulosus. Bile duct hyperplasia in brown bullhead liver. (A,B) Bile duct hyperplasia (A) in bullhead livers is characterized by an increased number of normal-appearing bile ducts (arrows) when compared to normal liver (B). Scale bars = $150 \mu \mathrm{m}$. (C) Hyperplastic bile ducts often have moderate fibrosis (arrows). Scale bar $=50 \mu \mathrm{m}$. (D) In some cases there is extensive fibrosis (a) around proliferating bile ducts (arrows). Scale bar $=50 \mu \mathrm{m}$. Hematoxylin \& eosin

\section{Neoplastic biliary lesions}

\section{Cholangioma}

Cholangiomas are usually nodular, well-defined neoplasms (Fig. 5A) that consist of moderately well-defined bile ducts with little fibrous connective tissue. In cholangiomas, clusters of bile ducts form expansive masses with discrete borders. Some cholangiomas feature dilated, irregularly shaped bile ducts. The duct epithelium is usually 1 cell layer thick, there is mild to moderate cellular atypia, and mitotic figures are uncommon (Fig. 5B).

\section{Cholangiocarcinoma}

Cholangiocarcinomas are comprised of atypical proliferating bile ducts that are admixed with an abun- dant, proliferating, fibrocellular stroma. These neoplasms display irregular, poorly defined borders where they often extend into the surrounding parenchyma (Fig. 5C,D). Proliferating bile ducts are usually irregularly shaped and the neoplastic epithelium is pleomorphic (Fig. 5E). The appearance of these tumors can vary from ductular structures within a moderately fibrous stroma (Fig. 5C) to poorly organized nests of biliary epithelial cells with numerous mitotic figures (Fig. 5F).

\section{DISCUSSION}

Laboratory studies on the pathogenesis of liver neoplasia in the bullhead are scarce. To our knowledge there is one documented experimental exposure in which 12 bullhead were fed a diet containing contaminated sediment extracts from the Black and Buffalo 


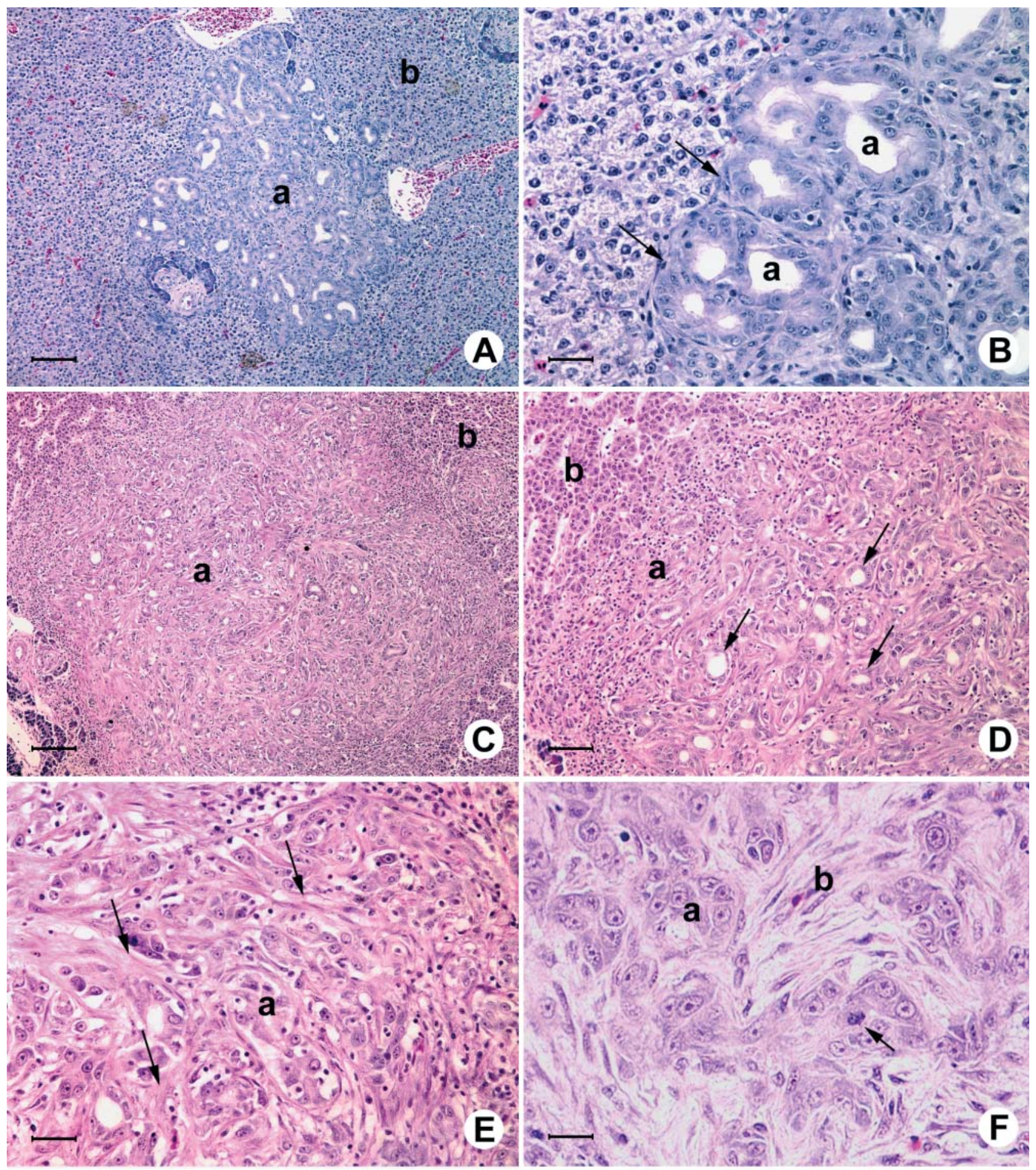

Fig. 5. Ameiurus nebulosus. Neoplastic biliary lesions in brown bullhead liver. (A) Cholangioma (a) is generally nodular and separated from normal hepatic tissue (b) by a well-defined border. Scale bar $=100 \mu \mathrm{m}$. (B) Higher magnification of (A) showing welldefined border (arrows) and epithelium of bile ducts (a), usually 1 cell thick but may be dilated and irregularly shaped. Scale bar $=$ $25 \mu \mathrm{m}$. (C) Cholangiocarcinoma composed of atypical proliferating bile ducts (a) with irregular, poorly defined border extending into surrounding parenchyma (b). Scale bar $=100 \mu \mathrm{m}$. (D) Higher magnification of (C) illustrating neoplastic bile ducts extending into normal hepatic parenchyma (b), eliciting an inflammatory reaction (a) at the border; normal-appearing ducts can still be observed in some areas (arrows). Scale bar $=50 \mu \mathrm{m}$. (E) Cholangiocarcinoma composed of irregularly shaped ducts (a) within a fibrocellular stroma (arrows). Scale bar $=25 \mu \mathrm{m}$. (F) In some cases, cholangiocarcinomas are composed of poorly organized nests of biliary epithelial cells (a) within a fibrocellular stroma (b); mitotic figure (arrow) can be observed. Scale bar $=25 \mu \mathrm{m}$. Hematoxylin \& eosin 
rivers (Black et al. 1985). In that experiment, 6 of the fish on the experimental diet were sacrificed after 4 mo and 6 were terminated after 7 mo. Lesions identified in the fish sacrificied at 4 mo included a basophilic focus, a small focus of bile duct proliferation, and a larger lesion consisting of mixed fibrosis and duct-like formations of hepatocytes. At $7 \mathrm{mo}$, findings included numerous clear cell and eosinophilic foci, bile duct proliferation and fibrosis, and a cholangioma. In a second study, brown bullhead were injected with a single intraperitoneal dose of $0,5,25$, or $125 \mathrm{mg} \mathrm{kg}^{-1}$ benzo[a]pyrene and evaluated over 18 mo (Grady et al. 1992); one focus of biliary hyperplasia and fibrosis in a bullhead exposed to $25 \mathrm{mg} \mathrm{kg}^{-1}$ and basophilic foci at all exposure levels were observed at Day 540. None of these lesions were observed in control fish. Unfortunately, none of the lesions in either study were described in detail or illustrated, nor was there any mention of control fish in the first study. Hence, further, more definitive studies are necessary to determine whether non-neoplastic proliferative lesions should be regarded as preneoplastic precursors of hepatocellular or biliary neoplasms in bullhead.

Foci of cellular alteration (basophilic, eosinophilic, vacuolated and clear cell) have been reported in neoplastic epizootics as well as carcinogenesis studies. There is evidence for the progression of basophilic foci to hepatocellular carcinoma in rainbow trout Oncorhynchus mykiss (Hendricks et al. 1984), medaka Oryzias latipes, guppies Poecilia reticulata (Hawkins et al. 1990), mosquitofish Gambusia affinis (Law et al. 1994), and sheepshead minnow Cyprinodon variegatus (Hinton et al. 1988), whereas there is no clear indication that other altered foci progress to neoplasia (Bunton 1996). However, several types of foci (vacuolated cell, eosinophilic and basophilic) that were observed in rivulus Rivulus ocellatus marmoratus exposed to diethylnitrosamine were considered preneoplastic (Grizzle \& Thiyagarajah 1988). Altered foci are also considered preneoplastic in wild English sole exposed to PAHs in Puget Sound (Myers et al. 1987, 1991), winter flounder from contaminated sites in Boston Harbor (Murchelano \& Wolke 1991), flounder from Dutch coastal areas (Vethaak \& Wester 1996), and British estuaries impacted by contaminants, including PAHs (Stentiford et al. 2003). Indeed, there is substantial evidence that increased prevalences of altered foci are associated with contaminant exposure, and should therefore be considered potential indications of such exposure and putatively pre-neoplastic.

Cholangiolar neoplasia has also been induced in numerous species through experimental contaminant exposures (Hendricks et al. 1984, Parland \& Baumann 1985, Couch \& Courtney 1987, Grizzle \& Thiyagarajah
1988, Hawkins et al. 1988, Law et al. 1994, Boorman et al. 1997). As with hepatic lesions, it has not been experimentally demonstrated which, if any, non-neoplastic cholangiolar changes may be considered preneoplastic in the bullhead. Proliferation of bile ductular epithelial cells has been observed during experimental chemical exposures in a number of species (Hendricks et al. 1984, Parland \& Baumann 1985, Couch \& Courtney 1987), and in such fishes the cells may be considered preneoplastic (Bunton 1996). Bile duct proliferation and fibrosis have also been reported in association with hepatic neoplasia in other fish species at a number of contaminated sites and are considered toxicopathic, and in some cases preneoplastic (May et al. 1987, Moore et al. 1989, Vogelbein et al. 1990, Baumann et al. 1991, Stehr et al. 2003). However, in bullheads, a myxosporidian parasite can commonly be observed within the lumen of bile ducts (Fig. 6A,B) and it is possible that bile duct proliferation and fibrosis may be related to the presence of this or other parasites. Similarly, a proliferative inflammatory response and giant cell formation has been observed in association with helminth parasites in the parenchyma of bullheads (Fig. 6C,D) and should not be confused with toxicopathic lesions.

In addition to the need for consistent diagnostic criteria, there is a need to establish consistent sampling procedures. A quality control issue for detection of neoplastic and other proliferative liver lesions concerns the number of histologic sections or levels in a liver that are necessary to accurately estimate the presence and extent in an individual liver. Stine et al. (2004) evaluated 6 livers from adult mummichog (a much smaller fish species than bullhead), 5 of which had grossly visible nodules. The authors discovered that: cancerous and precancerous lesions are not homogenously distributed; the presence of one lesion type may influence the extent and distribution of other lesions; multiple sections are needed (an average of 6 sections for $50 \%$ of lesions to be identified or 7 sections for $95 \%$ of lesion estimates to be included); and tissues sectioned in different planes and observations from different sections will generate different lesion observations and conclusions. In our studies, very few of the proliferative lesions diagnosed in bullhead were grossly apparent. Hence, it must be recognized that for large fish species such as adult brown bullhead more than 10 sections at various locations throughout the liver may be necessary to adequately estimate lesion prevalence.

One problem with the IJC 'fish tumors and other deformities' beneficial use impairment is that the phrase 'neoplastic or preneoplastic liver tumors' was never clearly defined. Certainly, hepatocellular adenoma, hepatocellular carcinoma, cholangioma and cholan- 

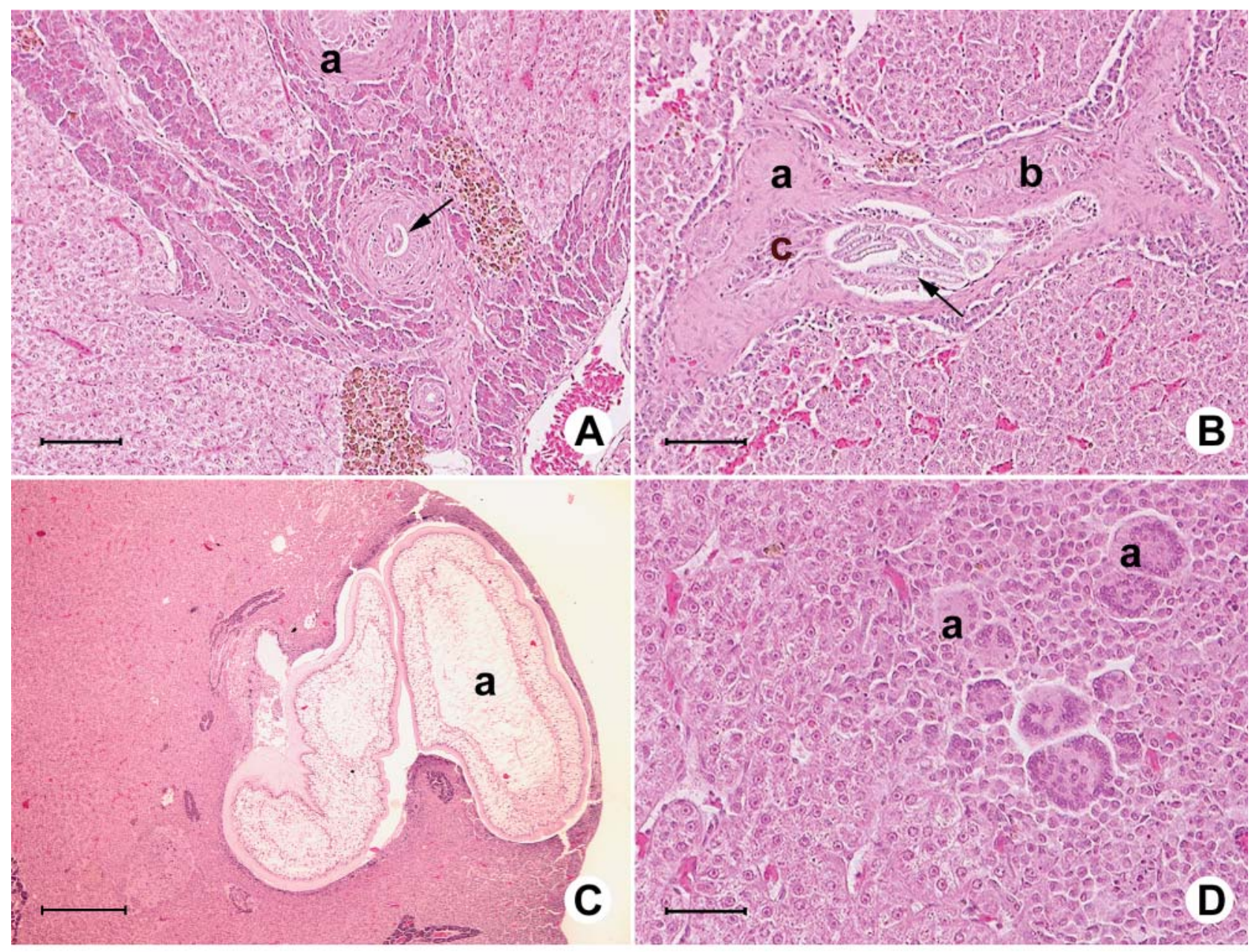

Fig. 6. Ameiurus nebulosus. Parasitic lesions in brown bullhead livers. (A,B) Fibrosis (a), ductule proliferation (b) and hyperplasia of ductule epithelium (c) can be observed around bile ducts that contain myxosporidian parasites (arrows). Scale bars $=100 \mu \mathrm{m}$. (C) Raised nodule in liver parenchyma caused by helminth parasite (a). Scale bar $=250 \mu \mathrm{m}$. (D) Inflammatory response to helminth parasites may include giant cell (a) formation. Scale bar $=50 \mu \mathrm{m}$. Hematoxylin \& eosin

giocarcinoma are neoplastic lesions that should be reported as such. Foci of cellular alteration, although not definitely shown to be preneoplastic in bullheads, should be viewed as putatively pre-neoplastic and should be documented in monitoring efforts. Bile duct proliferation and fibrosis may be related to contaminant exposure in some instances, but these may also be a result of parasite infection. Such lesions should not be considered preneoplastic, but should be documented and considered as potential toxicopathologic indicators.

Of necessity, survey studies that are used to assess the progress of AOC remediation efforts must be conducted at multiple time points that often span several years. Thus, it is inevitable that individual studies will be evaluated histologically by different pathologists, each of whom may have different training experiences and levels of expertise. Because of these factors, and the semi-subjective nature of histopathological evaluations, the consistency of results across studies may be somewhat less than desirable, and hence far from ideal for regulatory purposes. Thus, it would be desirable for each individual study to be peer-reviewed by a second pathologist who, like the initial pathologist, is familiar with the specific diagnostic criteria as described above. In addition, prior to the assimilation of study data into the regulatory decision-making process, we recommend that the collection of relevant studies be reviewed for diagnostic consistency and accuracy by a panel of fish pathology experts in a 'Pathology Working Group' format (Boorman et al. 1997). Slide collections such as those housed at the Registry for Tumors of Lower Animals are invaluable for comparative purposes, for retrospective analyses and development of diagnostic criteria for numerous lesions and fish species. 
Acknowledgements. Funding for this project was provided by Pennsylvania Sea Grant, US Geological Survey and the US Environmental Protection Agency. This project was performed, in part, by using the services provided by the National Cancer Institute's Registry of Tumors in Lower Animals, operated under contract by Experimental Pathology Laboratories, N02-CB-27034. We thank Lee Courtney for assistance in preparing the figures and Dr. William E. Hawkins for critically reviewing the manuscript.

\section{LITERATURE CITED}

Baumann PC (1989) PAH, metabolites, and neoplasia in feral fish populations. In: Varansi U (ed) Metabolism of polycyclic aromatic hydrocarbons in the aquatic environment. CRC Press, Boca Raton, FL, p 69-92

Baumann PC, Harshbarger JC (1995) Decline in liver neoplasms in the wild brown bullhead catfish after the coking plant closes and environmental PAHs plummet. Environ Health Perspect 103:168-170

Baumann PC, Harshbarger JC, Hartman KJ (1990) Relationship between liver tumors and age in brown bullhead populations from two Lake Erie tributaries. Sci Total Environ 94:71-87

Baumann PC, Mac MJ, Smith SB, Harshbarger JC (1991) Tumor frequencies in walleye (Stizostedion vitreum) and brown bullhead (Ictalurus nebulosus) and sediment contaminants in tributaries of the Laurentian Great Lakes. Can J Fish Aquat Sci 48:1804-1810

Baumann PC, Smith IR, Metcalfe CD (1996) Linkages between chemical contaminants and tumors in benthic Great Lakes fish. J Gt Lakes Res 22:131-152

Baumann PC, Cairns V, Kurey W, Lambert L, Smith I, Thoma $\mathrm{R}$ (2000) Fish tumors or other deformities. Lake Erie Lakewide Management Plan (LaMP) Tech Rep Ser No. 6. Great Lakes National Program Office, Chicago, IL

Black JJ (1983) Epidermal hyperplasia and neoplasia in brown bullheads (Ictalurus nebulosus) in response to repeated applications of a PAH containing extract of polluted river sediment. In: Cooke M, Dennis AJ (eds) Polynuclear aromatic hydrocarbons: formation, metabolism, and measurement. Battelle Press, Columbus, $\mathrm{OH}$, p 99-111

Black JJ, Fox H, Black P, Bock F (1985) Carcinogenic effects of river sediment extracts in fish and mice. In: Jolley RL, Bull RJ, Davis WP, Katz S, Roberts MH, Jacobs VA (eds) Water chlorination chemistry: environmental impact and health effects. Lewis Publishers, Chelsea, MI, p 415-427

Boorman GA, Botts S, Bunton TE, Fournie JW and 6 others (1997) Diagnostic criteria for degenerative, inflammatory, proliferative nonneoplastic and neoplastic liver lesions in medaka (Oryzias latipes): consensus of a National Toxicology Program pathology working group. Toxicol Pathol 25: 202-210

Bowser PR, Wolfe MJ, Reimer J, Shane BS (1991) Epizootic papillomas in brown bullheads Ictalurus nebulosus from Silver Stream Reservoir, New York. Dis Aquat Org 11: 117-127

Bunton TE (1996) Experimental chemical carcinogenesis in fish. Toxicol Pathol 24:603-618

Couch JA, Courtney LA (1987) $N$-nitrosodiethylamineinduced hepatocarcinogenesis in estuarine sheepshead minnow (Cyprinodon variegatus): neoplasms and related lesions compared with mammalian lesions. J Natl Cancer Inst 79:297-321

Feist SW, Lang T, Stentiford GD, Köhler A (2004) Biological effects of contaminants: use of liver pathology of the European flatfish dab (Limanda limanda L.) and flounder (Platichthys flesus L.) for monitoring. ICES Tech Mar Environ Sci 38:42

Gardner GR, Pruell RJ, Folmer LC (1989) A comparison of both neoplastic and non-neoplastic disorders of winter flounder (Pseudopleuronectes americanus) from eight areas in New England. Mar Environ Res 28:393-397

Gingerich WH (1982) Hepatic toxicology of fishes. In: Weber LJ (ed) Aquatic toxicology. Raven Press, New York, p 55-105

Grady AW, McLaughlin RM, Caldwell CW, Schmitt CJ, Stalling DL (1992) Flow cytometry, morphometry and histopathology as biomarkers of benz[a]pyrene exposure in brown bullhead (Ameiurus nebulosus). J Appl Toxicol 12:165-177

Grizzle JM, Thiyagarajah A (1988) Diethylnitrosamineinduced hepatic neoplasms in the fish Rivulus ocellatus marmoratus. Dis Aquat Org 5:39-50

Harshbarger JC, Clark JB (1990) Epizootiology of neoplasms in bony fish of North America. Sci Total Environ 94:1-32

Hawkins WE, Walker WW, Overstreet RM, Lytle JS, Lytle TF (1988) Dose-related carcinogenic effects of water-borne benzo[a]pyrene on livers of two small fish species. Ecotoxicol Environ Saf 16:219-231

Hawkins WE, Walker WW, Overstreet RM, Lytle JS, Lytle TF (1990) Carcinogenic effects of some polycyclic aromatic hydrocarbons on the Japanese medaka and guppy in waterborne exposures. Sci Total Environ 94:155-167

Hayes MA, Smith IR, Rushmore TH, Crane TL, Thorn C, Kocal TE, Ferguson HW (1990) Pathogenesis of skin and liver neoplasms in white suckers from industrially polluted areas in Lake Ontario. Sci Total Environ 94:105-123

Hendricks JD, Meyers TR, Shelton DW (1984) Histological progression of hepatic neoplasia in rainbow trout (Salmo gairdneri). Natl Cancer Inst Monogr 65:321-336

Hinton DE, Couch JA (1998) Architectural pattern, tissue and cellular morphology in livers of fishes: relationship to experimentally-induced neoplastic responses. In: Braunbeck $T$, Hinton DE, Streit B (eds) Fish ecotoxicology. Birkhäuser, Basel, p 141-164

Hinton DE, Couch JA, Teh SJ, Courtney LA (1988) Cytological changes during the progression of neoplasia in selected fish species. Aquat Toxicol (Amst) 11:77-112

Hinton DE, Segner H, Braunbeck T (2001) Toxic responses of the liver. In: Schlenk D, Benson WH (eds) Target organ toxicity in marine and freshwater teleosts. Taylor \& Francis, London, p 224-268

IJC (International Joint Commission) (1987) Guidance on characterization of toxic substance problems in areas of concern in the Great Lakes Basin. Surveillance Work Group. International Joint Commission, Windsor, ON

IJC (International Joint Commission) (1989) Proposed listing/ delisting criteria for the Great Lakes areas of concern. Focus on international joint commission activities, Vol 14, Issue 1. International Joint Commission Windsor, ON

Köhler A (2004) The gender-specific risk to liver toxicity and cancer of flounder (Platichthys flesus (L.)) at the German Wadden Sea coast. Aquat Toxicol 70:257-276

Law JM, Hawkins WE, Overstreet RM, Walker WW (1994) Hepatocarcinogenesis in western mosquitofish (Gambusia affinis) exposed to methylazoxymethanol acetate. J Comp Pathol 110:117-127

Maccubbin AE, Ersing N (1991) Tumors in fish from the Detroit River. Hydrobiologia 219:301-306

Maccubbin AE, Black P, Trzeciak L, Black JJ (1985) Evidence for polynuclear aromatic hydrocarbons in the diet of 
bottom-feeding fish. Bull Environ Contam Toxicol 34: 876-882

May EB, Lukacovic R, King H, Lipsky MM (1987) Hyperplastic and neoplastic alterations in the livers of white perch (Morone americana) from the Chesapeake Bay. J Natl Cancer Inst 79:137-143

Metcalfe CD (1998) Toxicopathic responses to organic compounds. In: Leatherland JF, Woo PTK (eds) Fish diseases and disorders, Vol 2. Non-infectious disorders. CABI Publishing, Oxon, p 132-162

Moore MJ, Smolowitz R, Stegeman JJ (1989) Cellular alterations preceding neoplasia in Pseudopleuronectes americanus from Boston Harbor. Mar Environ Res 28:425-429

Mueller ME, Mac MJ (1994) Fish tumors and abnormalities. Assessment and remediation of contaminated sediments (ARCS) program: assessment guidance document. US Environmental Protection Agency, Chicago, IL

Murchelano RA, Wolke RE (1991) Neoplasms and nonneoplastic liver lesions in winter flounder, Pseudopleuronectes americanus, from Boston Harbor, Massachusettes. Environ Health Perspect 90:17-26

Myers MS, Rhodes LD, McCain BB (1987) Pathologic anatomy and patterns of occurrence of hepatic neoplasms, putative preneoplastic lesions, and other idiopathic hepatic conditions in English sole (Parophrys vetulus) from Puget Sound, Washington. J Natl Cancer Inst 78:333-363

Myers MS, Landahl JT, Kahn MK, Johnson LL, McCain BB (1990) Overview of studies on liver carcinogenesis in English sole from Puget Sound; evidence for a xenobiotic chemical etiology I. Pathology and epizootiology. Sci Total Environ 94:33-50

Myers MS, Landahl JT, Kahn MK, McCain BB (1991) Relationships between hepatic neoplasms and related lesions and exposure to toxic chemicals in marine fish from the US West coast. Environ Health Perspect 90:7-15

Parland WK, Baumann PC (1985) Pathology and tumor development through time in guppies dosed with diethylnitrosamine (DEN). J Appl Toxicol 5:265-272

Pinkney AE, Harshbarger JC, May EB, Melancon MJ (2001) Tumor prevalence and biomarkers of exposure in brown bullheads (Ameiurus nebulosus) from the tidal Potomac River, USA, watershed. Environ Toxicol Chem 20: 1196-1205

Editorial responsibility: Thomas Lang,

Cuxhaven, Germany
Poulet FM, Wolfe MJ, Spitsbergen JM (1994) Naturally occurring orocutaneous papillomas and carcinomas of brown bullheads (Ictalurus nebulosus) in New York state. Vet Pathol 31:8-18

Pyron M, Obert EC, Wellington R (2001) Tumor rates and population estimates of brown bullhead (Ameiurus nebulosus) in Presque Isle Bay, Lake Erie. J Great Lakes Res 27: 185-190

Rocha E, Monteiro RAF (1999) Histology and cytology of fish liver: a review. In: Saksena DN (ed) Ichthyology: recent research advances. Science Publishers, Enfield, $\mathrm{NH}, \mathrm{p} 321-344$

Smith IR, Ferguson HW, Hayes MA (1989) Histopathology and prevalence of epidermal papillomas epidmic in brown bullhead, Ictalurus nebulosus (Lesueur), and white sucker, Catostomus commersoni (Lacépède), population from Ontario. Canada. J Fish Dis 12:373-388

Smith SB, Bouin MA, Mac MJ (1994) Ecological comparisons of Lake Erie tributaries with elevated incidences of fish tumors. J Great Lakes Res 20:701-716

Sonstegard RA (1977) Environmental carcinogenesis studies in fishes of the Great Lakes of North America. Ann NY Acad Sci 298:261-269

Stehr CM, Myers MS, Johnson LL, Spencer S, Stein JE (2003) Toxicopathic liver lesions in English sole and chemical contaminant exposure in Vancouver Harbour, Canada. Mar Environ Res 57:55-74

Stentiford GD, Longshaw M, Lyons BP, Jones G, Green M, Feist SW (2003) Histopathological biomarkers in estuarine fish species for the assessment of biological effects of contaminants. Mar Environ Res 55:137-159

Stine CB, Smith DL, Vogelbein WK, Harshbarger JC, Gudla PR, Lipsky MM, Kane AS (2004) Morphometry of hepatic neoplasms and altered foci in the mummichog, Fundulus heteroclitus. Toxicol Pathol 32:375-383

Vethaak AD, Wester PW (1996) Diseases of flounder Platichthys flesus in Dutch coastal and estuarine waters with particular reference to environmental stress factors. II. Liver histopathology. Dis Aquat Org 26:99-116

Vogelbein, WK, Fournie JW, Van Veld PA, Huggett RJ (1990) Hepatic neoplasms in the mummichog Fundulus heteroclitus from a creosote-contaminated site. Can J Res 50: 5978-5986

Submitted: October 26, 2005; Accepted: May 12, 2006

Proofs received from author(s): August 29, 2006 